\title{
Assessment of Farmers' Perception on the Role of Agroforestry in Improving the Livelihood of the Rural Farming House Holds: The Case of Bedelle District. Oromia, Ethiopia
}

\author{
Zenebe Reta* \\ College of Agriculture and Forestry, Mettu University, P.O. Box 318, Bedelle, Ethiopia
}

\begin{abstract}
The study was carried out in bedelle district. The major objective of the study was to assess the role of agro forestry to improve the rural farming household in the district. The factors that affect the farmers' perception on agro forestry practices were both positive and negative. In the study out of 802 house hold 5\% were selected by using stratified sampling techniques based on their relative wealth categories in order to have the exact and unbiased information on the farmer' perception on the role of agro forestry in improving the livelihood. These techniques of data collection was attained and data was summarized in the form of tables and histogram Among these increasing supply food, fodder, fuel wood and services like soil erosion control and increasing the organic matter by litter fall were the positive factors. Whereas the negative factors were practicing conventional tillage and introduction of allopathic tree species which results in yield reduction from agro forestry practices. The results of the study area showed that the land use system consists of different types of agro forestry practices and among these were: home gardens, wood lots, scattered trees in crop land, live fence and animal production with crop provide different goods and services for the local farmers. Based on the problem identified in the study area we should avoid introduction of exotic tree species which are invasive and having alelopathic effect and instead practice local one providing the productivity to agro forestry.
\end{abstract}

Keywords: agro forestry, farmers" perception, household and livelihood.

DOI: $10.7176 / \mathrm{JAAS} / 52-04$

\section{Introduction.}

Cultivating trees together with agricultural crops and livestock an ancient practice that farmers have over the world the farmer grow the trees in their farm land to increase the productivity of the land (Nair, 1995). Especially in the tropics trees were the essential component of the follow vegetation on temporality abandoned field and many trees were also kept without specific purpose on farm land were they did not interfere while the use of land for crop cultivation (mc nearly scoth,2006). It has been traditional practiced by the villagers' farm land and grazing lands in home comes and or home garden and as a wind break and shelter belts. This is used today use say agro forestry (Nair, 1995).

The objectives of agro forestry are not only producing trees, it was also for producing wood. Many factors and development in 1970s contributed to the general acceptances of agro forestry as a system of land management that is applicable for both farm and forest. The factor that increase the acceptance was high spread of tropical deforestation and ecological degradation 1970s energy crises, shortage of fertilizer and high prices the scarcity and the degradation of land as a result of population pressures, food shortage in many developing countries an increasing of scientific interest in both inter cropping and farming system and redesigning of the forest policy by FAO. These all reason gives birth to social forest and agro forestry (Nair 1993)

Agro forestry is the collective name for land use system and practice in which woody perennial are deliberately integrated with crop and/or animal on the same land management units. The integration can be either in special mixture on temporal sequence. There are normally both ecological and economic integration between wood and none woody component in agro forestry (ICRAE, 1993). This definition implies that an agro forestry system is two or more species plant or animal one of which is woody perennial the two or more out puts and the cycle of agro forestry is more than one year and simple agro forestry system in more complex ecologically (structurally and functionally) and economically than them no cropping system (Nair 1993).

An agro forestry system holds the three attributes such as productivity, sustainability and adaptability. The productivity attribute refer to one of the purpose of agro forestry system in to increase production and to improve the productivity of the land through increasing the out of the tree and crop yields sustainability approach refer agro forestry practice conserves the soil and the environment as a result it gives favorable environment to the continuous production. Adaptability attributes means when the agro forestry technology becomes to produce or introduce in the new places, it considers the interest of farmers and the attributes, the agro forestry simply adopted by the user or the farmer (Nair, 1993).

The combination of several types of products in agro forestry which are both subsistence and income generation help the farmer to meet their basic needs and minimizing the risk of the production system failures (ICRA, 1993). It has been suggested by several development experts as the new solution to rural development 
need (Rocheleau et al, 1989). Hence, this study intended to investigate assessment of farmers 'perception on the role of agro forestry in improving the livelihood of the rural farming households: the case bedelle district .Therefore, this study is designed with the following objective.

$>$ To assess the role of agro forestry in improving livelihood of rural household.

$>$ To assess the perception of local people on agro forestry practices.

$>$ To assess the management of agro forestry practices applied by local farmers.

\section{Materials and Methods.}

\subsection{Description of the study area.}

\subsubsection{Location}

From the zone of oromia region Bedelle is the one, which is located $485 \mathrm{~km}$ far from Addis Ababa and $115 \mathrm{~km}$ from Illu Ababor zone.

The district receives minimum and maximum annual rain fall ranges from $900-1300 \mathrm{~mm}$ respectively and temperature ranges $10-28^{0} \mathrm{c}$. The dry season in the area extends from November to April and wet season is from May to October. The intensity of rain fall becomes very high at july and August .

The district has an estimated total population 98500 people in which 47325 male and 51175 .

The vegetation was mostly localized around hill and some area in the river and flat lands. Among them most of them are indigenous and some are exotic once. The indigenous species include junipera procera; podocarpus vicus vasta and other are the domain trees found in and around farm land and grazing land in the form of dense and scattered trees. In the area the traditional home garden agro forestry and wood lot were most commonly used and practiced.

In the district, the farmer practice both farming crop and livestock's most crop provided by the farmer were wheat, barley, potato and dominantly Avocado, coffee and chat. The farmer also practice crop like cabbage and other vegetable crops, livestock in the area were reared cow, horse, hen and donkey.

\subsection{Sampling techniques}

The district has woyna dega type of agro ecological condition. The sampling technique was stratified random sampling design $5 \%$ of the total household farmers taken based on wealth rank out 41 respondents farmers 13 from rich(high annual income farmers) 14 from middle income and 14 from poor (low income)farmers because of their homogeneity of farming system in the area this would help to gather detail information. The representative 41 household were selected and the study was achieved by this sampling technique. The finding was finding was depend on variables of population to be conducted time taken, cost and accessibilities of district favors in terms of environmental factor and resources development house hold were selected and this number is considered as maximum which will be handled effectively conducted within the research time and budget.

\subsection{Data sources}

The research includes two data collection component, these are house hold survey and in farm agro forestry assessment in order to get primary data and also secondary data are used.

\subsubsection{Primary data sources}

Primary data are collected by developing formal (prepared) question and interviewing those who are conserved bodies (farmers, district development agent, woreda agriculture office experts) and on farm agro forestry observation. A focus questioner was demonstrated on the role, perception and management of agro forestry practices stratified random sampling used to select house hold from each wealth status category in the district.

\subsubsection{Secondary data sources}

Secondary data were collected from the district agriculture office and kebele extension workers document, published and unpublished paper which are available in $\mathrm{G} / \mathrm{G} / \mathrm{W}$ woreda.

\subsection{Data collection}

The data were collected through prepared questioner by interviewing the concerned body especially farmers and district development agent (DA) and agricultural office experts the questioner focus on what advantage are identified by practicing agro forestry practice what is the farmer perception on agro forestry practices in improving.

Their livelihood and what type of management practice are employed by farmers in agro forestry land use type in addition to this personal field observation was conducted to identify problem related to agro forestry practice and type of agro forestry management practices.

\subsubsection{Data analysis}

The information that was obtained from structured interview gathered data organized analyzed and summarized by using simple descriptive statically analysis method the result expressed in percentage, range and an average result will be tabulated. 


\section{Results and Discussion}

3.1. Background of respondents

3.1.1. Age structure of respondents.

Figure3.1. Structure and economic level age structure.

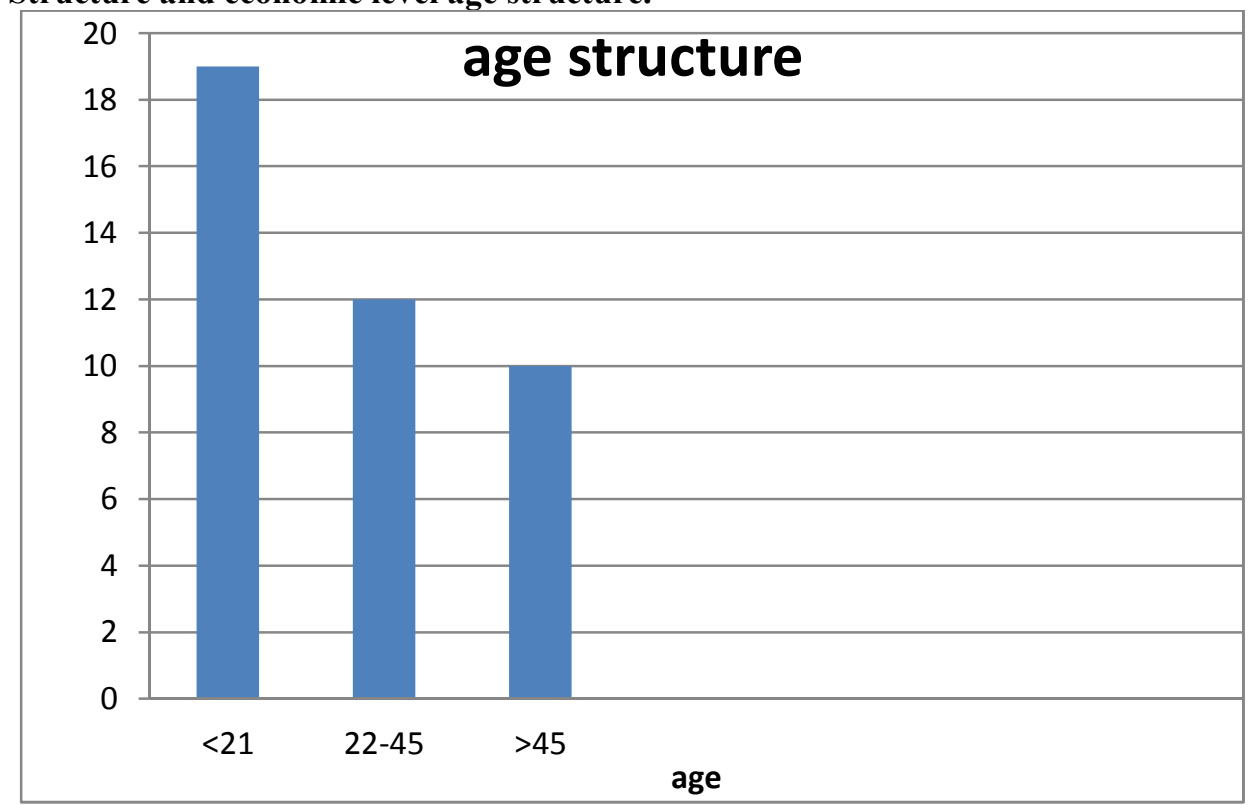

Sources (survey, 2018).

According to the age distribution of the respondent from the above graph show that most of the respondents are fall in the productive age group (22-45) and they have the understanding about agro forestry as compared to the other relative age group.

\subsubsection{Educational status}

Table3.1. Educational status of respondents

\begin{tabular}{llll}
\hline No. & Educational level & No. of respondents & Respondent in percent \% \\
\hline $\mathbf{1}$ & Cannot read and write & 18 & 45 \\
$\mathbf{2}$ & Can read and write & 9 & 22.5 \\
$\mathbf{3}$ & First cycle(1-4) & 10 & 25 \\
$\mathbf{4}$ & Secondary cycle(5-8) & 2 & 5 \\
$\mathbf{5}$ & High school $(>$ grade 9$)$ & 2 & 2.5 \\
& Total & 41 & 100 \\
\hline
\end{tabular}

Source own survey, 2018

The discussion of the respondents in to these different educational level implies that these different educational level they have different understanding about agro forestry system. The respondent in the higher educational level have the good implication about agro forestry and similarly their understanding varies as their educational level become less.

\subsection{Types of agro forestry practices in the study area}

The land use system in the study area include crop production, animal rearing and woodlot plantation the food crop cultivation in the land use system includes coffee, , maize, chat, avocado and cabbage are the major ones. The trees in the land system are crton macrostachyus, junipers, and podocarpus and evavptus species.

\subsubsection{Home garden}

Table3.2. Home garden agro forestry system

\begin{tabular}{llll}
\hline No. & Types of home garden plant & No. of respondents & Respondent in percent \\
\hline $\mathbf{1}$ & Cabbage (Brassica sp.) & 41 & 100 \\
$\mathbf{2}$ & Coffee (Coffea arabica) & 18 & 44 \\
$\mathbf{3}$ & Maize (Zea mays) & 21 & 51 \\
$\mathbf{4}$ & Avocado (Persea americana) & 41 & 100 \\
$\mathbf{5}$ & Enset (Enset vertricosum) & 13 & 32 \\
$\mathbf{6}$ & Chat (Chata edulis) & 16 & 39 \\
& Average percentage & - & 61 \\
\hline
\end{tabular}

Source own survey, 2018 
The farmer in the study area cultivate home garden agro forestry includes, chat, coffee, maize, avocado and cabbage among them all the respondents have practice instead cabbage. The farmer most of the time select enset crop due to high food supply to the farmers, drought resistance and its soil and water conservation potential. It was also used as fodder for their cattle during dry season the coffee and chat was to generate cash income in order to satisfy their basic needs.

The other home garden crop such as cabbage maize avocado provides food for farmers and sometimes generates income generally average percent of the respondents who were practice home agro forestry $61 \%$ this was because due to home garden agro forestry provides a lot of benefits. But type of crop and the abundance of crop in home garden were different cultivation of different crop in home garden have the strategy of the farmer to develop their subsistence and cash needs. It also helps to stabilize their yield and income in the case of the incidence of disease, pest and at a time of market price fluctuation.

The common management practices applied by the local farmers were weeding, hoeing, pruning (for tree and coffee) mourning, fencing and watering are major ones.

\subsubsection{Scattered trees in crop lands}

The practice of scattered trees in crop land involves the growing of individual tree and shrubs in wide space in the crop land.

Table 3.3.Scatterd trees in the crop land

\begin{tabular}{lll}
\hline Type of tree & No of respondent & Percent \\
\hline Bisaba (Croton macrostachyus) & 27 & 66 \\
Yekoso zaf (Hagenia abyssinica) & 33 & 80 \\
Zigiba (Podocarpus falcatus) & 35 & 85 \\
Korch (Erythrina brucei) & 39 & 95 \\
Avocado (Persea americana) & 13 & 32 \\
Total average percent & & 71.6 \\
\hline
\end{tabular}

Source: own survey, 2018

The scattered trees were sparsely planted in the field in order to minimize the impact of companion crop of the system and have potentials for supplying fodders, farming tools, fuel wood and fiber, soil fertility improvement by their litter fall and water conservation.

Among the scatterd trees in the crop land Podocarpus falcatus and Erythrina brucei dominantly used by the farmer due to their fast growing, litter fall which improve the soil fertility and timber production; some of the scattered trees have medicinal value to the farmer. Such as Hagenia abyssinica is used for heal of tape worm. These scattered trees also supplied fuel wood and farming tool to the local farmers and also the scattered trees are used to increase soil organic matter by litter fall, conservation of soil and water and also used as sources of fuel wood and fodder

\subsubsection{Woodlot plantation}

Table3.4. of wood lots

\begin{tabular}{lll}
\hline Types of the species & No. Of respondents & Percent \\
\hline Bamboo (Yushina alpina) & 32 & 78 \\
Zigiba (Podocarpus falcatus) & 35 & 85 \\
Yeabesha Tid (Juniperus procera) & 30 & 73 \\
Nechi Bahir Zaf (Eucalyptus globulus) & 41 & 100 \\
Average percentage & & 84 \\
\hline
\end{tabular}

\section{Source: own survey, 2018}

In the study area dominantly farmer practice eucalyptus plantation this is because of most of the time farmers generate fuel and construction wood from eucalyptus and also it grows very fast and also provided goods in the short period of time. The farmers also gain income by selling in the local market. Juniperus procera and Podocarpus falcatus also used as house and fence construction and generating income. The energy sources of the respondent were described in table as follows.

Table3.5. Energy sources of the respondents

\begin{tabular}{lll}
\hline Source of energy & No. Of respondents & Percent \\
\hline Fuel wood & 41 & 100 \\
Electric for light & 6 & \\
Gas(kerosene) for light & 28 & \\
Animal dung & 4 & \\
Total & & \\
\hline
\end{tabular}

Source: own survey, 2018

All most all the respondents in the study area were used fuel wood as a source of household energy for preparation of their foods and heating their homes in the area. Some of the respondents uses kerosene and 
electric for light purpose in their home but not used for food cooking and heating. This is because the farmers can't able to afford the cost of buying electricity. This indicates that the dominant energy in the study area was fuel wood, especially from eucalyptus tree and the scattered trees and shrub in their farm land.

\subsubsection{Animal production with crops}

Animal production with crops is one of the types of agro forestry practice which is practiced by the all farmers in the study area. The types of animal and their uses are presented in the following table.

Table3.6. Animal production with crops

\begin{tabular}{llll}
\hline Types of animal reared & No. of respondents & Percentage & Uses \\
\hline Cows & 41 & 100 & Milk, meat \& dung \\
Sheep & 41 & 100 & Meat, skin and dung \\
Horses & 29 & 71 & Transporting and dung \\
Oxen & 6 & 15 & Meat, plowing and dung \\
Goat & 10 & 34 & Meat and hide \\
Donkey & 6 & 15 & Transporting and dung \\
Hen & 32 & 78 & Meat and egg \\
\hline
\end{tabular}

Source: own survey, 2018

The animal reared in the study area were includes cow, sheep, goat, hen, donkey, horse and oxen are the major ones. The dominant reared animal by the respondents were cows and sheep because the multi production potential of the cow for providing meat, milk, skin, dung used as manuring their land and also to gain cash income by selling the cows and sheep's in the local market. These different animals provide commonly the cash income and to obtain the natural fertilizer to their agro forestry crop. The farmers practiced rearing of animal with their crop in order to supplement their food supply of the household and to improve to soil fertility which increases the productivity of their crops in agro forestry.

\subsubsection{Live fence}

Live fence is one of the most commonly used fences for both demarcating the boundary and protecting the interaction and interference of animal to their agro forestry it out lined as follow in table.

Table3.6. Live fence

\begin{tabular}{lccc}
\hline Types of tree used as live fence & No. of respondents & Percentage & Uses \\
\hline Zongereal /local name/ & 39 & 95 & $\begin{array}{c}\text { Demarcating boundary and } \\
\text { fencing } \\
\text { Yeferenji Tid (Cupressus lustanica) }\end{array}$ \\
Korch (Erythrina brucei) & 31 & 76 & $\begin{array}{c}\text { Hedge purpose } \\
\text { For fencing }\end{array}$ \\
Average percentage & 37 & 90 & $\begin{array}{c}\text { Demarcating boundary and } \\
\text { fencing }\end{array}$
\end{tabular}

\section{Source: own survey, 2018}

The dominantly used species for live fence in the study area were lateral (local name) which was used by the farmer in the study area. The farmer select the species because of its fast growing none-alelopothic, high decomposable litter and adaptability of the local climatic and it can easily grow.

\subsection{Impact of agro forestry systems}

Table3.8. Impact agro forestry practice in the study area

\begin{tabular}{|c|c|c|c|c|c|}
\hline Positive impact & $\begin{array}{c}\text { No. of } \\
\text { respondents }\end{array}$ & Percentage \% & Negative impact & $\begin{array}{c}\text { No. of } \\
\text { respondents }\end{array}$ & Percentage $\%$ \\
\hline Source of food, fodder & 41 & 100 & $\begin{array}{l}\text { Competing with } \\
\text { each other for } \\
\text { resource }\end{array}$ & 20 & 50 \\
\hline Cash income & 28 & 68 & $\begin{array}{l}\text { Introducing exotic } \\
\text { species }\end{array}$ & 11 & 27 \\
\hline $\begin{array}{l}\text { Soil fertility } \\
\text { improvement }\end{array}$ & 39 & 95 & & & \\
\hline Control soil erosion & 26 & 63 & & & \\
\hline Source of fuel wood & 41 & 100 & & & \\
\hline
\end{tabular}

Source: own survey, 2018

In the study area one of the negative impact of agro forestry practice completing of agro forestry component each other especially crop of the for light, water, nutrient and space. Introduction of exotic species specifically the invasive species affecting the practice of agro forestry by invading the field and grow excursively. The study 
area the eucalyptus species which invade the species grow around it and by its deep root absorb the ground water and evaporate to the atmosphere in turn create shortage or water an associated crops grow near to it. There are many factors that promote the farmer then to practice the agro forestry in the study area. The food, fodder, cash income increase soil organic matter, control soil erosion and as source of fuel wood was the major factor which promote agro forestry practice of the farmer in the area.

The continuous supply of food, fodder and fuel wood grow agro forestry in order to five both ecological service and economic gain the local farmers as a result these positive impact of agro forestry promote the farmers to practice agro forestry systems over negative impact.

\subsection{Farmer' perception towards agro forestry}

According to different type of agro forestry practice which describe above the perception of local farmers towards agro forestry practices are out lined as follows, based on the local farmers.

Table3.9. Perception of farmers about agro forestry

\begin{tabular}{lll}
\hline $\begin{array}{l}\text { Types of agro } \\
\text { forestry practice }\end{array}$ & $\begin{array}{l}\text { Average } \\
\text { respondents in percent \% }\end{array}$ & $\begin{array}{l}\text { no. } \\
\text { Woodlots }\end{array}$ \\
\hline Home garden & 79 & $\begin{array}{l}\text { Construction material, fibber fuel, wood preparation of } \\
\text { farming tools and generating cash income. } \\
\text { Food, fodder, fuel wood, cash income, soil and water } \\
\text { conservation } \\
\text { Improve soil organic matter content, providing fuel wood } \\
\text { and for making farming tools } \\
\text { Demarking farmers field boundary's and protecting crops } \\
\text { from damaging by animal and humans }\end{array}$ \\
Live fence & 82 & \\
\hline
\end{tabular}

\section{Source: own survey, 2018}

The perception of local farmers towards agro forestry practice was positive. All farmers in the study area were dependants on agro forestry systems to obtain food from their home garden and rearing animal with crops; fuel wood from agricultural land which is the basic need of house holder farmers. The farmers also obtain cash income from selling of agro forestry products specially chat, and wood from eucalyptus species all farmers in the study area use enset for their food consumption as a fodder for their animals specially during drought season.

\subsection{Management practice employed by farmers for agro forestry practice}

The farmer who had practiced agro forestry in Gora kebele carries out different management practice during different season of the year. during September and October they apply management practice like weeding, hoeing and mulching and in April and may animal manuring, completion and pruning of tree which have large branches in order to avoid completion for light between the component and during rainy season in June and July planting trees and coffee seedling in the area of melted tree during rainy season the survey result about management practice include by farmers presented as follow in the table.

Table3.10. Types of management practices for agro forestry employed by the farmers

\begin{tabular}{lll}
\hline Management practice types & $\begin{array}{l}\text { Number of farmers } \\
\text { practice management }\end{array}$ & percentage \\
\hline Weeding & 41 & 100 \\
Animal manuring & 41 & 100 \\
Composting & 12 & 29 \\
Planting tree and coffee seedling in b/n & 36 & 88 \\
available space due to tree and coffee wilting & &
\end{tabular}

\section{Source: own survey, 2018}

Based on the above table data which were obtained from respondent farmers and field observation $100 \%$ of the respondent farmer practiced animal manuring and weeding of their farm field occupied by agro forestry where as only $29 \%$ of the farmer use composting in order to improve the productivity of their land. The reason behind this most of the farmers have negative perception about compost due to lack of enough knowledge and skill about compost preparation and related to this they believed that compost lead disease like sinus $88 \%$ of the respondent planting tree and coffee also enset seedling in the agro forestry in the place of harvested component and welted trees.

\section{Conclusion and recommendation.}

The socio-economic survey results showed that all household live in the area practiced one or other type of agro forestry practice but the good and service obtained by individual farmer were different according to the management type and the size of agro forestry which they practiced however, the most observed was the home 
garden type of agro forestry.

Generally agro forestry has provide a lot of role to livelihood of rural community of the district through supplying goods (food, fodder, timber cash income) and service (shade, soil fertility improvement, ecological stabilization) to the local farmers. Fodder agro forestry tree and crop are used as buffer to overcome the feed gap arises from the seasonal fluctuation are factors that affect the practice of agro forestry in the study area. These factors were both positive and negative. The positive factors that facilitate the agro forestry practice are supplying of food, fodder, fuel wood and construction wood and also ecological protection of soil against erosion and stabilize the microclimate of agro forestry landscape, Introduction of exotic species in the system and competition of resources between components were considered as negative factors but obtaining continuous supply of agro forestry products and ecological services from the agro forestry practices more enable the farmer to reflect positive perception towards agro forestry practices in the area. Therefore, the following points are recommended.

$>$ One of the negative impact of agro forestry practice in the study area was introduction of exotic species completion between component of agro forestry practices to overcome this problem by avoiding exotic species especially eucalyptus species and substitute by indigenous one is very important.

$>$ Using tree crop which should provide adequate spacing between them in order to reduce competition for resources between crops and trees.

> Practicing fast growing tree which have no alelophathic effect and better adapt to local climate condition and multipurpose tree species deliberately growing agricultural crop better to protect the area from the effect of climatic change and provide fodder continuously for their animal throughout the year.

\section{REFERENCES.}

$>$ FAO (2005) realizing the economic benefit of agro forestry experiences, lesson and challenges. The state of the world forest.

> Fernandes E.c.m,Okting A,and Maghembas (1989), the change home gardens ;a multi storied agro forestry cropping system on Kilimanjaro (Northeren fanzania)

$>$ ICRAF (1993), Report the first external problem and management review of the international center of research in agro forestry role of agro forestry in improving food security and natural resources management of the dry land.

> Mc,Neely, J.A and scorth, G(2006). Agro forestry and biodiversity conservation, traditional practice, present dynamic and lesson for the future.

$>$ Nair P,K,R,(1989) agro forestry intropics, kluwer dord rech the,Netherland

> Nair P,K,R,(1993) an introduction of agro forestry, kluwer academic publisher,dordrech the,Netherland

$>$ Okafor J.C. and Fernand Ec.m (1987) the compound form of south eastern Nigeria a predominant agro forestry home garden system with crop and live stock

$>$ poschenP.(1989). An evaluation of acacia albidia based on agro forestry practice in the Hardee highland of Ethiopia in agro forestry in tropic"Nair (RD). RocheleauD.(1989) local knowledge for agro forestry and native plants intermediate publication technology London.

$>$ Report (2016). Woreda agricultural department office report.

$>$ Singh,S.P.(1994) Hand book of agro forestry agro technique publishing academy Haran manage.

> Young A. (1989) agro forestry for soil conservation ICRAFCA B. International Wallingford,UK. 